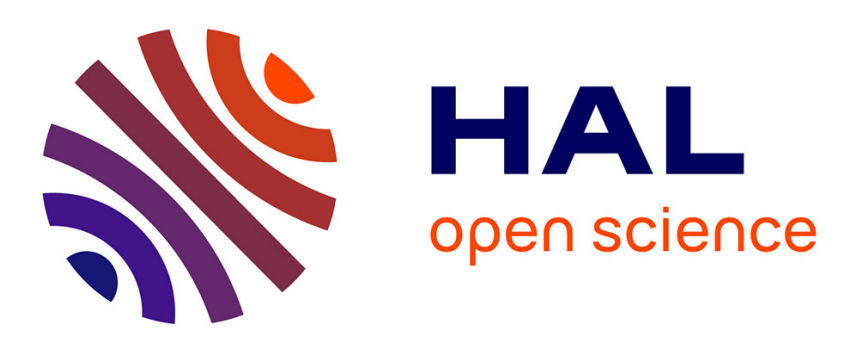

\title{
Segmental bioelectrical impedance analysis (SBIA) and blood rheology: Reducing the gap between in vivo and in vitro?
}

Emmanuelle Varlet-Marie, Céline Joré, Jean-Frédéric Brun

\section{- To cite this version:}

Emmanuelle Varlet-Marie, Céline Joré, Jean-Frédéric Brun. Segmental bioelectrical impedance analysis (SBIA) and blood rheology: Reducing the gap between in vivo and in vitro?. Clinical Hemorheology and Microcirculation, 2017, 64 (4), pp.603 - 611. 10.3233/CH-168041 . hal-01804152

\section{HAL Id: hal-01804152 \\ https://hal.umontpellier.fr/hal-01804152}

Submitted on 10 Dec 2019

HAL is a multi-disciplinary open access archive for the deposit and dissemination of scientific research documents, whether they are published or not. The documents may come from teaching and research institutions in France or abroad, or from public or private research centers.
L'archive ouverte pluridisciplinaire HAL, est destinée au dépôt et à la diffusion de documents scientifiques de niveau recherche, publiés ou non, émanant des établissements d'enseignement et de recherche français ou étrangers, des laboratoires publics ou privés. 


\title{
Segmental bioelectrical impedance analysis (SBIA) and blood rheology: Reducing the gap between in vivo and in vitro?
}

\author{
Emmanuelle Varlet-Marie ${ }^{\mathrm{a}, \mathrm{b}}$, Céline Joré ${ }^{\mathrm{b}, \mathrm{d}}$ and Jean-Frédéric Brun ${ }^{\mathrm{c}, *}$
}

a Institut des Biomolécules Max Mousseron (IBMM) UMR CNRS 5247, Université de Montpellier, Ecole Nationale Supérieure de Chimie de Montpellier, France

${ }^{\mathrm{b}}$ Laboratoire de Biophysique \& Bio-Analyses, Faculté de Pharmacie, Université de Montpellier, France ${ }^{\mathrm{c}}$ UMR CNRS 9214-Inserm U1046 «Physiopathologie \& Médecine Expérimentale du Cœeur et des Muscles - PHYMEDEXP », Unité d'Explorations Métaboliques (CERAMM), Université de Montpellier, Département de Physiologie Clinique, Hôpital Lapeyronie CHU Montpellier, France

${ }^{\mathrm{d}}$ Laboratoire des Courses Hippiques, Verrières le Buisson, France

\begin{abstract}
Bioelectrical impedancemetry (BIA) has been used to evaluate hematocrit and red cell aggregability in vitro but whole body impedance measurements are also correlated to some hemorheologic factors, suggesting a relationship between viscosity factors and electric properties of blood. We repeatedly reported correlations with whole body BIA and hematocrit, whole blood viscosity and plasma viscosity, red cell rigidity and RBC aggregation. The SBIA Inbody 770 modelizes body as 5 cylinders and measures impedance at $1,5,50,250,500$, and $1000 \mathrm{kHz}$. With the SBIA we found that hematocrit is best correlated to leg reactance at $50 \mathrm{kHz}$ but also to leg impedance at 1 and $5 \mathrm{kHz}$ and trunk reactance. RBC aggregation "M" is best correlated to arm reactance at $5 \mathrm{kHz}$ but also to most measurements of segmental impedance (28 correlations found). RBC aggregation "M1" is best correlated to arm reactance at $5 \mathrm{kHz}$ and to 19 other impedance measurements. A predictive equation for " $\mathrm{M}$ " from the mean between the two arm reactances at $5 \mathrm{kHz}$ ( $\mathrm{maXc5}$ ) is found: $\mathrm{M}=2.1845 \mathrm{maXc5}$ $23.958(r=0.665, p<0.001)$ that provides a satisfactory Bland-Altman plot (mean difference: 0.000524 range $[-1.6 ;+1.6]$. This study suggests that previously reported correlations between BIA and viscosity factors were not spurious, and that in a narrow cylinder such as the arm the structure of circulating blood (hematocrit, red cell aggregation) may influence the passage of an electric current by increasing reactance.
\end{abstract}

Keywords: Segmental bioelectrical impedance, hematocrit, myrenne aggregometer, red blood cell aggregation, electrical conductance, light transmission

\section{List of symbols}

BIA Bioelectrical impedancemetry

RBC red blood cell

SEM standard error on the mean

\section{Introduction}

Bioelectrical impedancemetry (BIA) has been investigated with the aim of proposing new in vitro techniques for evaluating hematocrit and red cell aggregability in vitro [1]. The fair correlations found

${ }^{*}$ Corresponding author: Jean-Frédéric Brun, UMR CNRS 9214-Inserm U1046 « Physiopathologie \& Médecine Expérimentale du Cœur et des Muscles - PHYMEDEXP », Unité d'Explorations Métaboliques (CERAMM), Université de Montpellier, Département de Physiologie Clinique, Hôpital Lapeyronie CHU Montpellier, France. Tel.: +33 467338284; Fax: +33 467338986; E-mail: j-brun@chu-montpellier.fr. 
Table 1

Clinical characteristics of the 10 subjects of the study (mean + SEM)

\begin{tabular}{lc}
\hline Age (years) & $22.00 \pm 1.88$ \\
Weight $(\mathrm{kg})$ & $75.23 \pm 10.91$ \\
Height $(\mathrm{cm})$ & $181.00 \pm 5.35$ \\
Body mass index $\left(\mathrm{kg} / \mathrm{m}^{2}\right)$ & $22.81 \pm 2.74$ \\
Hematocrit $(\%)$ & $45.79 \pm 3.30$ \\
\hline
\end{tabular}

in vitro between BIA and these hemorheologic parameters lead to think that they may influence the electrical properties of the whole body. Accordingly, we repeatedly reported correlations between electrical properties of the whole body (impedance, resistance, reactance) and some hemorheologic factors (hematocrit, whole blood viscosity and plasma viscosity, red cell rigidity and RBC aggregation). However these correlations were difficult to interpret $[4,20]$ and it was likely that the complex shape of the human body was the mean reason for this. More recently segmental bioimpedance has become largely available and provides a more precise prediction of body composition $[3,5]$. The robustness of this approach is largely due to the fact that trunk, arms and legs are separately analyzed as cylinders whose impedance reflect their own biophysical properties.

The SBIA Inbody 770 is one of the most recent devices of segmental BIA and it modelizes body as 5 cylinders, measuring their impedance at 1, 5, 50,250,500, and $1000 \mathrm{kHz}$. From these measurements it provides a set of values of reactance and impedance at various frequencies for the 5 segments of body. We investigated whether such parameters were correlated to hematocrit and red cell aggregation during a protocol where they were measured before and after injection of a single dose of the erythropoietin analogue methoxy polyethylene glycol-epoetin- $\beta$ (Mircera $\left.{ }^{\circledR}\right)$.

\section{Subjects and methods}

\subsection{Study subjects}

Characteristics of subjects are shown in Table 1 . They were included in a study aiming at investigating whether a single injection of the long acting erythropoietin analogue methoxy polyethylene glycolepoetin- $\beta$ (Mircera) can be detected by various analytical procedures including metabolomics and proteomics. In this study we also measured red cell aggregability and the results of this aggregability study are shown in a separate paper. In the current paper we only focus on the relationships between impedance data and hemorheologic measurements.

\subsection{Bioelectrical impedance measurements}

Bioimpedance analysis as performed with the SBIA Inbody 770 impedancemeter kindly provided for this study by InBody FRANCE, 515 Rue Alfred Nobel, 34000 Montpellier (France). This device measures total resistance of the body to an alternative electric current of very low intensity at the following frequencies: $1,5,50,250,500,1000 \mathrm{kHz}$.

DSM-BIA was performed using the In-Body (770) body composition analyzer. This equipment has previously been shown to have high test-pretest reliability and accuracy [5]. Unlike conventional BIA equipment which often takes only partial measurements and therefore relies upon formulas to estimate whole body composition, the DSM-BIA technique employs the assumption that the human body is composed of 5 interconnecting cylinders and takes direct impedance measurements from the 
various body compartments. A tetrapolar eight-point tactile electrode system is used, which separately measures impedance of the subject's trunk, arms, and legs at six different frequencies $(1 \mathrm{kHz}, 5 \mathrm{kHz}$, $50 \mathrm{kHz}, 250 \mathrm{kHz}, 500 \mathrm{kHz}, 1000 \mathrm{kHz}$ ) for each of the body segment. The In-Body (770) body composition analyzer has in-built hands and feet electrodes. Subjects wore normal indoor clothing and advised to stand barefooted in upright position with their feet on the feet electrodes on the machine platform and their arms abducted with hands gripping on to the hands electrodes on the handles. Subjects were not require to fast for the test $[8,10,11,19]$ The results that interested us in this study were crude values of electric parameters, i.e. impedance, resistance and reactance in all segments analyzed by the BIA.

\subsection{Hemorheological in vitro measurements}

Blood samples for hemorheological measurements $(7 \mathrm{ml})$ were drawn with potassium EDTA as the anticoagulant in a vacuum tube (Vacutainer). RBC aggregation was assessed with the Myrenne aggregometer [17] which gives two indices of RBC aggregation: " $\mathrm{M}$ " (aggregation during stasis after shearing at $600 \mathrm{~s}^{-1}$ ) and "M1" (facilitated aggregation at low shear rate after shearing at $600 \mathrm{~s}^{-1}$ ). Hematocrit was measured together with other hematological markers with the Coulter analysis.

\subsection{Statistics}

Results are presented as mean \pm the SEM. A value of $p<0.05$ was considered as significant. Comparisons were made with nonparametric tests. Correlations were tested by least square fitting for linear, exponential, logarithmic and power relationships.

\section{Results}

The main results of this experiment are presented in a separate paper. After injection of Mircera ${ }^{\circledR}$ a decrease in mean RBC corpuscular volume at day $2(p<0.01)$ and day $10(p<0.02)$, a rise in reticulocyte count $(p<0.001)$ between day 4 and day 17 and a decrease in ferritin a day $5(p<0.05)$ were evidenced. Hemoglobin decreased at day $4(p<0.005)$. Hematocrit was unchanged. There was a dramatic $(+67 \%)$ increase in RBC aggregation index " $\mathrm{M}$ " (from $9.49 \pm 1.01$ to $17.66 \pm 1.8 p<0.01$ ). A decrease in systolic blood pressure was also observed during the period from day 4 to day 17 (at day 10: $-11.90 \pm 2.28 \mathrm{mmHg} p<0.001$; at day $17:-15.80 \pm 2.83 p<0.001$. There was also a decrease in diastolic blood pressure, mean and pulse pressure. All these results are commented in a separate study.

Table 2 shows all the significant correlations that were found between the hemorheological parameters studied here (i.e., RBC aggregation and hematocrit) and impedance measurements.

As shown on Fig. 1 hematocrit is best correlated to leg reactance at $50 \mathrm{kHz}$ (left leg $r=0.410$ $p<0.001)$. It is also correlated to right leg reactance $(r=0.353 p<0.01)$, to leg impedance at 1 and $5 \mathrm{kHz}$, and to trunk reactance (see Table 2).

$\mathrm{RBC}$ aggregation " $\mathrm{M}$ " is best correlated to arm reactance at $5 \mathrm{kHz}$ (right arm $r=0.659 p<0.001$ (Fig. 2); left arm $r=0.617 p<0.001$ ) but also to most measurements of segmental impedance ( 28 correlations found). RBC aggregation "M1" is best correlated to arm reactance at $5 \mathrm{kHz}$ (right arm $r=0.549 p<0.001$; left arm $r=0.511 p<0.001$ ) and to 19 other impedance measurements. Finally a predictive equation for " $M$ " from the mean between the two arm reactances at $5 \mathrm{kHz}$ (maXc5) is found: $\mathrm{M}=2.1845 \mathrm{maXc5}-23.958(r=0.665 p<0.001)$ that provides a satisfactory Bland-Altman plot (mean difference: 0.000524 range $[-1.6 ;+1.6]$ (Fig. 3 ). 
Table 2

Coefficients of correlation between measurements of segmental BIA and the three hemorheolgic parameters measured in the study.

\begin{tabular}{|c|c|c|}
\hline $\begin{array}{l}\text { Main predictors of } \\
\text { hematocrit }\end{array}$ & $\begin{array}{l}\text { Main predictors of } \\
\text { RBC aggregation "M" }\end{array}$ & $\begin{array}{l}\text { Main predictors of } \\
\text { RBC aggregation "M1" }\end{array}$ \\
\hline $50 \mathrm{kHz}-\mathrm{LL} \mathrm{Xc}$ & $5 \mathrm{kHz}-\mathrm{RA} \mathrm{Xc}$ & $5 \mathrm{kHz}-\mathrm{RA} \mathrm{Xc}$ \\
\hline$r=0.410$ & $r=0.660$ & $r=0.549$ \\
\hline $50 \mathrm{kHz}-\mathrm{LA} \mathrm{Xc}$ & $5 \mathrm{kHz}-\mathrm{LA} \mathrm{Xc}$ & $5 \mathrm{kHz}-\mathrm{LA}$ \\
\hline$r=0.353$ & $r=0.617$ & $r=0.511$ \\
\hline $5 \mathrm{kHz}-\mathrm{LL} \mathrm{Xc}$ & $5 \mathrm{kHz}-\mathrm{RL} \mathrm{Z}$ & $1 \mathrm{kHz}-\mathrm{RL} \mathrm{Z}$ \\
\hline$r=0.353$ & $r=0.462$ & $r=0.453$ \\
\hline $50 \mathrm{kHz}-\mathrm{RA} \mathrm{Xc}$ & $1 \mathrm{kHz}-\mathrm{RL} \mathrm{Z}$ & $5 \mathrm{kHz}-\mathrm{RL} \mathrm{Z}$ \\
\hline$r=0.344$ & $r=0.462$ & $r=0.450$ \\
\hline & $50 \mathrm{kHz}-\mathrm{RA} \mathrm{Xc}$ & $50 \mathrm{kHz}-\mathrm{RL}$ Xc Z \\
\hline & $r=0.454$ & $r=0.439$ \\
\hline & $50 \mathrm{kHz}-\mathrm{RL} \mathrm{Xc}$ & $50 \mathrm{kHz}-\mathrm{RA}$ Xc \\
\hline & $r=0.448$ & $r=0.420$ \\
\hline & $1 \mathrm{Mhz}-\mathrm{RL} \mathrm{Z}$ & $50 \mathrm{kHz}-\mathrm{RL} \mathrm{Z}$ \\
\hline & $r=0.446$ & $r=0.418$ \\
\hline & $250 \mathrm{kHz}-\mathrm{LL} \mathrm{Xc}$ & $1 \mathrm{Mhz}-\mathrm{RL} \mathrm{Z}$ \\
\hline & $r=0.440$ & $r=0.416$ \\
\hline & $50 \mathrm{kHz}-\mathrm{RL} \mathrm{Z}$ & $500 \mathrm{kHz}-\mathrm{RL} \mathrm{Z}$ \\
\hline & $r=0.432$ & $r=0.403$ \\
\hline & $500 \mathrm{kHz}-\mathrm{RL} \mathrm{Z}$ & $250 \mathrm{kHz}-\mathrm{RL} \mathrm{Z}$ \\
\hline & $r=0.426$ & $r=0.394, p<0.01$ \\
\hline & $50 \mathrm{kHz}-\mathrm{LL} \mathrm{Xc}$ & $50 \mathrm{kHz}-\mathrm{LA} \mathrm{Xc}$ \\
\hline & $r=0.416$ & $r=0.369, p<0.01$ \\
\hline & $250 \mathrm{kHz}-\mathrm{RL} \mathrm{Z}$ & $50 \mathrm{kHz}-\mathrm{LL} \mathrm{Xc}$ \\
\hline & $r=0.413$ & $r=0.354, p<0.01$ \\
\hline & $1 \mathrm{kHz}-\mathrm{LL} \mathrm{Z}$ & $5 \mathrm{kHz}-\mathrm{RL} \mathrm{Xc}$ \\
\hline & $r=0.410$ & $r=0.335, p<0.02$ \\
\hline & $5 \mathrm{kHz}-\mathrm{LL} \mathrm{Z}$ & 1 kHz-LL Z \\
\hline & $r=0.405$ & $r=0.331, p<0.02$ \\
\hline & $50 \mathrm{kHz}-\mathrm{LL} \mathrm{Z}$ & $5 \mathrm{kHz}-\mathrm{LL} \mathrm{Z}$ \\
\hline & $r=0.389$ & $r=0.319, p<0.05$ \\
\hline & $50 \mathrm{kHz}-\mathrm{LA} \mathrm{Xc}$ & $250 \mathrm{kHz}-\mathrm{LL}$ Xc \\
\hline & $r=0.378$ & $r=0.313, p<0.05$ \\
\hline & $250 \mathrm{kHz}-\mathrm{LL} \mathrm{Z}$ & $50 \mathrm{kHz}-\mathrm{LL} \mathrm{Z}$ \\
\hline & $r=0.362$ & $r=0.299, p<0.05$ \\
\hline & $500 \mathrm{kHz}-\mathrm{LL} \mathrm{Z}$ & $5 \mathrm{kHz}-\mathrm{LL} \mathrm{Xc}$ \\
\hline & $r=0.355$ & $r=0.296, p<0.05$ \\
\hline & $1 \mathrm{Mhz}-\mathrm{LL} \mathrm{Z}$ & $250 \mathrm{kHz}-\mathrm{LL} \mathrm{Z}$ \\
\hline & $r=0.348$ & $r=0.273, p<0.05$ \\
\hline & $50 \mathrm{kHz}-\mathrm{TR} \mathrm{Xc}$ & \\
\hline & $r=0.340$ & \\
\hline & $5 \mathrm{kHz}-\mathrm{TR} \mathrm{Z}$ & \\
\hline & $R=0.336$ & \\
\hline & $5 \mathrm{kHz}-\mathrm{RA}$ Phase Angle & \\
\hline & $r=0.335$ & \\
\hline
\end{tabular}


Table 2

(Continued)

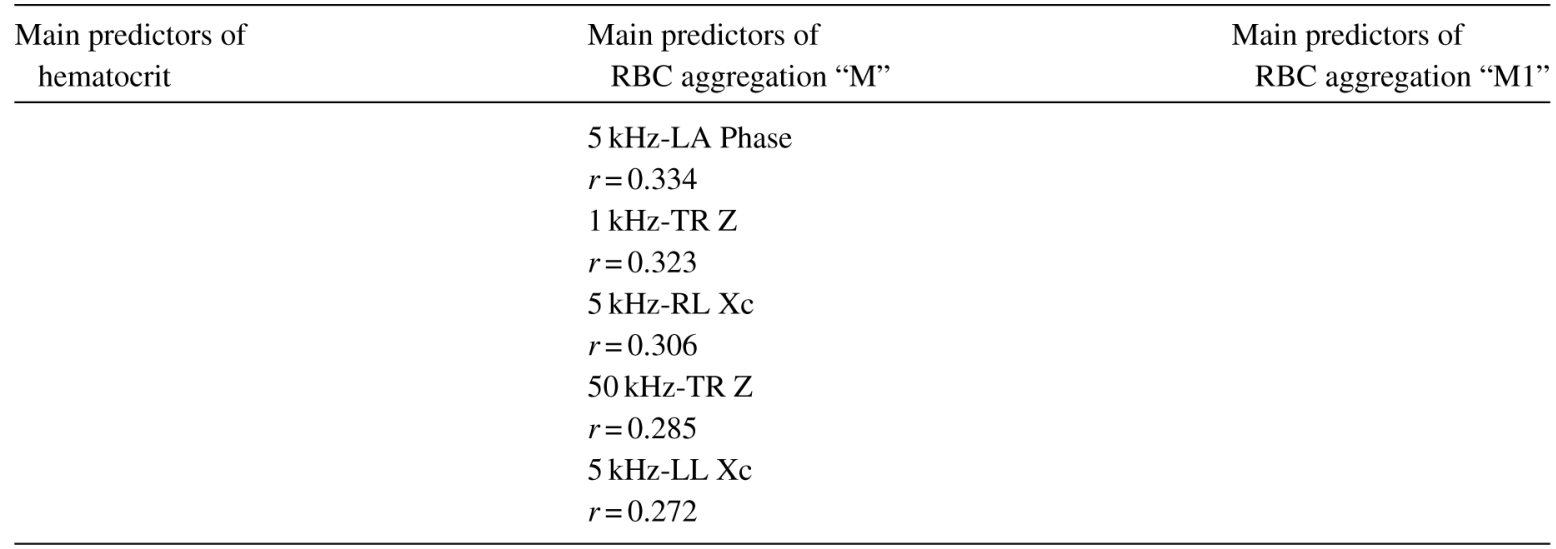

Abbreviations: $\mathrm{Xc}=$ reactance; $\mathrm{Z}=$ impedance; $\mathrm{LL}=$ left leg; $\mathrm{LA}=$ left arm; $\mathrm{RA}=$ right arm; $\mathrm{LA}=$ left arm; $\mathrm{TR}=$ trunk.

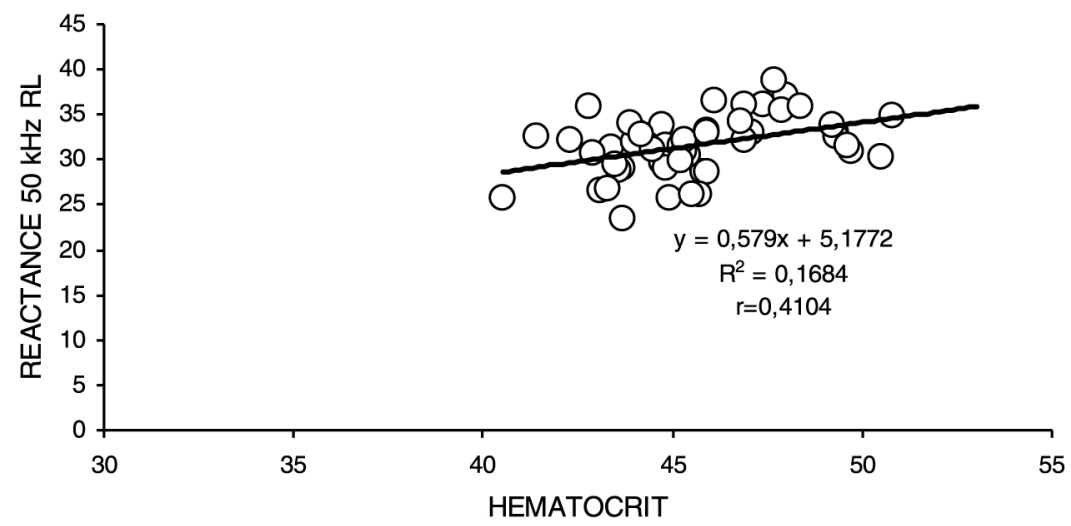

Fig. 1. Positive correlation between systemic hematocrit and leg reactance at $50 \mathrm{kHz}$.

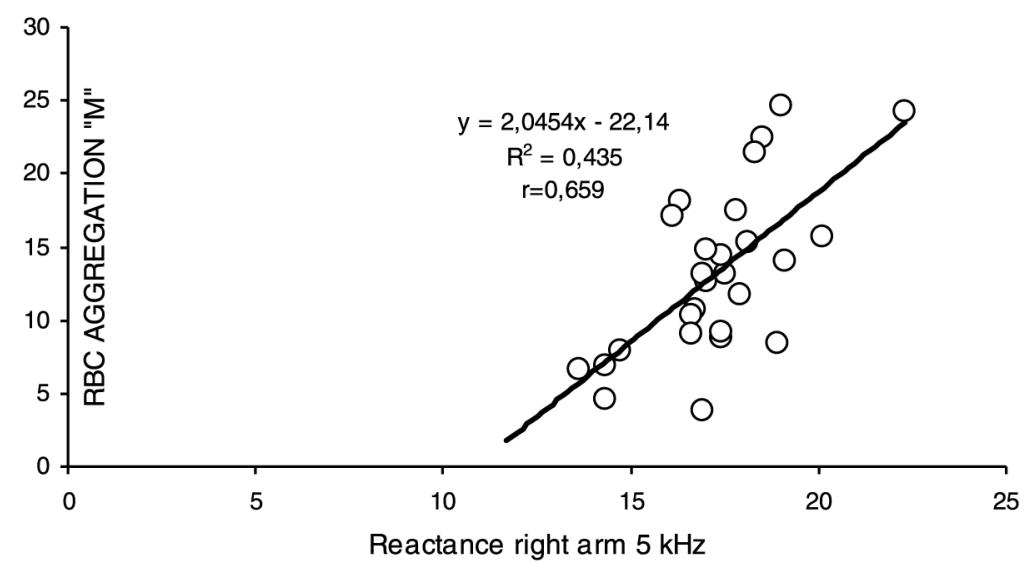

Fig. 2. Positive correlation between red cell aggregation "M" and right arm reactance at $5 \mathrm{kHz}$. 

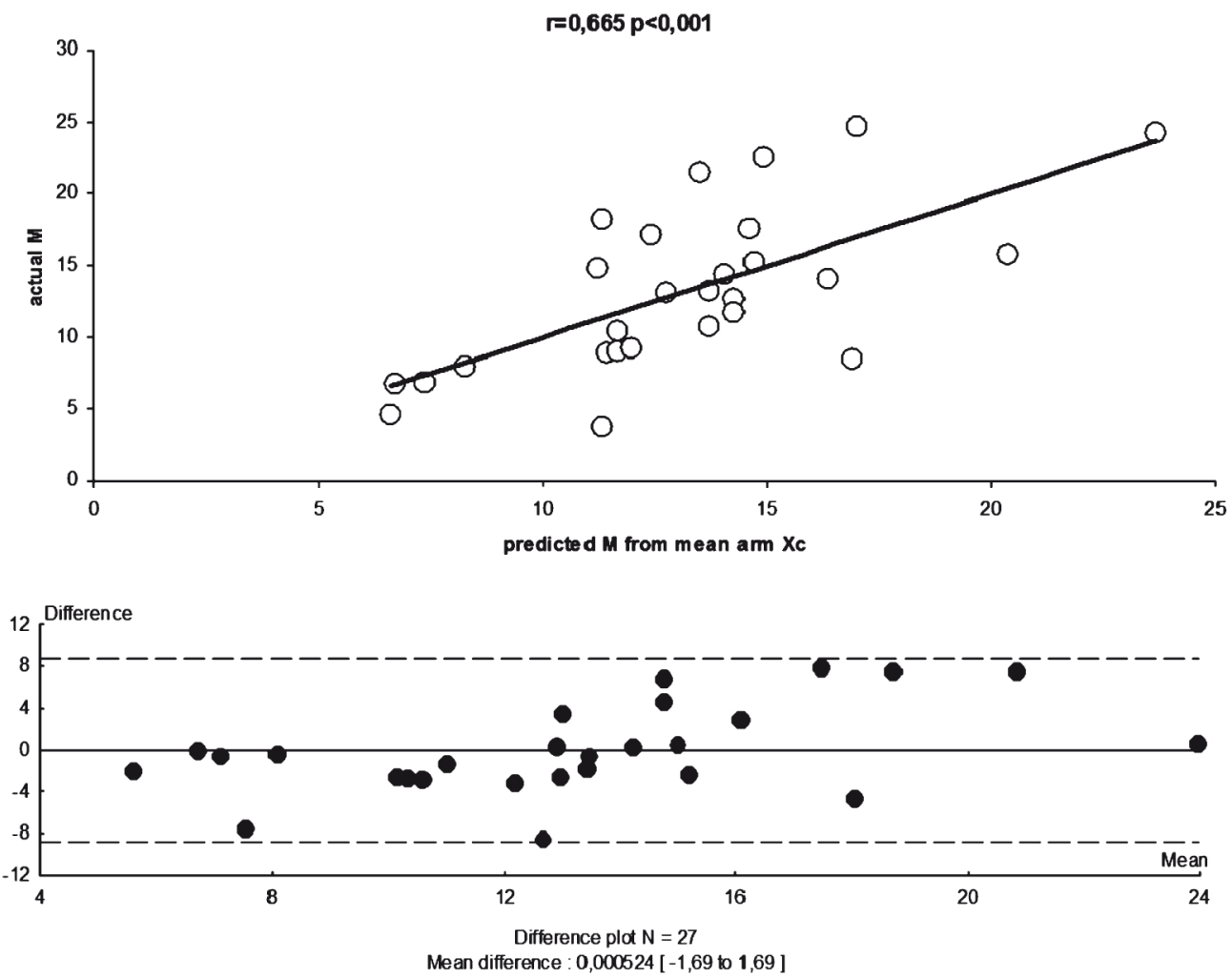

Fig. 3. Agreement of a prediction of RBC aggregation index " $M$ " with its value predicted with the equation: $M=2.1845$ maXc5-23.958 with maXc5 being the mean of reactances of the two arms. Upper pannel: correlation coefficient; lower pannel: Bland-Altman plot.

\section{Discussion}

Bioelectrical impedance analysis is widely used for the routine assessment of fat mass, fat free mass and body fluid volumes $[16,22]$ but there are other determinants of the electric properties of the body that affect the impedance of living tissues and thus can be reflected to some extent by BIA measurements.

This study evidences a host of correlations between BIA crude measurements and both haematocrit and red cell aggregability. Among them, the most significant are between hematocrit and leg reactance at $50 \mathrm{kHz}$, and between arm reactance at $5 \mathrm{kHz}$ and $\mathrm{RBC}$ aggregation index " $\mathrm{M}$ ". We show a predictive equation for " $\mathrm{M}$ " from the mean between the two arm reactances at $5 \mathrm{kHz}$ that provides a quite satisfactory Bland-Altman plot.

In preceding studies using whole body BIA (see review in $[4,21]$ we reported several predictions of viscosity factors with $\mathrm{r}$ coefficients ranging between $r=0.441$ and $r=0.761$ but their meaning was sometimes difficult to understand. All are shown on Table 3.

Although some of the previous correlations shown on Table 3 yielded satisfactory coefficients of correlations and/or Bland-Altman plots, the correlations shown here are probably more accurate than those we previously reported in our preceding papers using whole body BIA. Both hematocrit and red cell aggregation are known to increase the impedance of blood in vitro or measured by electrodes set within vessels directly in the blood flow, and this is exactly what is reflected with our in vivo measurements. 
Table 3

Previously reported equations predicting viscosity factors from whole body BIA measurements.

\begin{tabular}{lll}
\hline Formula & $\begin{array}{c}\text { Correlation } \\
\text { coefficient }\end{array}$ & $\begin{array}{c}\text { Bland-Alman plot: } \\
\text { mean difference (range). }\end{array}$ \\
\hline Hct $=50.42 \exp \left(-3.07 \cdot 10^{-4} Z_{1}\right)$ & $r=-0.485$ & $-0.187(-0.976-0.602)$ \\
WBV $=-513.4069 Z_{100}+4.1466$ & $r=0.518$ & $5.9 \times 10^{-5}(-0.127-0.127)$ \\
PV $=1.07+0.00568$ & $r=0.441$ & $0.023(-0.0242+0.0289)$ \\
$\quad(\mathrm{W} / \mathrm{FFM})-0.000154 Z_{10}$ & & \\
$\mathrm{Hct}=-0.029 Z_{50}+54.621$ & $r=-0.591$ & $-0.0335(-0,686-0,619)$ \\
$\mathrm{Hct}=-0.0352 Z_{50}+58.741$ & $r=-0.686$ & $0(-1.04-1.04)$ \\
$\mathrm{WBV}=-0.0032 Z_{50}+4.8621$ & $r=-0.541$ & $-1.82 \times 10^{-5}(-1.04-1.04)$ \\
$\mathrm{k}=0,005809 \mathrm{Re} / \mathrm{ECW}+1,1784$ & $r=0,487$ & $0124(-0,00481-0,00296)$ \\
$\mathrm{M}=-27,4755 \rho_{\mathrm{e}}+1121,57029$ & $r=0.463$ & $94(-0,842-0,842)$. \\
$\mathrm{S}_{10}=-59,38579\left(\rho_{\mathrm{e}}-40\right)+63,083$ & $r=0.761$ & $0,000722(-1,77-1,77)$.
\end{tabular}

References

Varlet-Marie et al., Clin Hemorheol Microcirc 28 (2003) 129-137

Varlet-Marie et al., Clin Hemorheol Microcirc 28 (2003) 129-137

Varlet-Marie et al., Clin Hemorheol Microcirc 28 (2003) 129-137

Varlet-Marie et al., Clin Hemorheol Microcirc 30 (2004) 471-475

Varlet-Marie et al., Clin Hemorheol Microcirc 30 (2004) 393-398

Varlet-Marie et al., Clin Hemorheol Microcirc 30 (2004) 393-398 393

Brun et al., Series on Biomechanics 25(1-2) (2010) 100-104

Brun et al., Series on Biomechanics 25(1-2) (2010) 100-104

Brun et al., Series on Biomechanics 25(1-2) (2010), 100-104

Abbreviations: Hct $=$ hematocrit; $\mathrm{WBV}=$ whole blood viscosity at $1000 \mathrm{~s}-1 ; \mathrm{Z} 1=$ whole body impedance at a frequency of $1 \mathrm{kHz} ; \mathrm{Z} 10=$ whole body impedance at a frequency of $10 \mathrm{kHz} ; \mathrm{Z} 50=$ whole body impedance at a frequency of $50 \mathrm{kHz}$; $\mathrm{Z} 100=$ whole body impedance at a frequency of $100 \mathrm{kHz}$; PV = plasma viscosity; W/FFM =water in fat free mass calculated by whole body BIA at $50 \mathrm{kHz}$; "k" = red blood cell rigidity index calculated from viscometry with Quemada's equation; ECW: extracellular water volume calculated with; $\mathrm{Re}=$ extracellular resistance and $? \mathrm{e}=$ extracellular resistivity predicted with Hanai's mixture conductivity theory. according to Jaffrin [7]; M= Myrenne index of red blood cell aggregation (see text); "S10 SEFAM index of red blood cell aggregation.

The measurement of red cell aggregation used in this study is the most classical and widely used one. It has been recently shown to be well correlated with the measurement of the yield stress provided by viscometric measurements, supporting its validity [10]. On the other hand, in vitro experiments conducted by the late Oguz Baskurt show that despite some discrepancies electrical conductance and light transmission of aggregating blood at various hematocrits in plasma or in isotonic saline have similar time courses and are related to each other [2]. Concerning hematocrit, all in vitro studies [6, 14, $15,18]$ show that it increases impedance, and this is also found with electrodes put in vivo in the blood stream $[12,13]$. Therefore the equation found in this paper is also logic. By contrast it is still difficult to understand why in whole body measurements we repeatedly evidenced negative correlations, that are fully contra-intuitive.

\section{Conclusions}

On the whole this study evidences a correlation between hematocrit and leg reactance, and a correlation between red cell aggregation and arm reactance. Further testing of this approach is needed. This study suggests that the previously reported correlations between whole body BIA and viscosity factor were probably not spurious, and that in a narrow cylinder such as the arm the structure of circulating blood (hematocrit, red cell aggregation) may influence the passage of an electric current by increasing 
reactance. Whether this may provide a reliable window on hemorheology remains of course to be studied.

\section{Acknowledgments}

The authors affirm that they have no disclosure of interest concerning the issue investigated in this paper. This study was presented as oral communication at the 18th European Conference on Clinical Hemorheology. June 2016, Lisbon.

\section{References}

[1] N. Antonova, P. Riha and I. Ivanov, Time dependent variation of human blood conductivity as a method for an estimation of RBC aggregation, Clinical Hemorheology and Microcirculation 39 (2008), 69-78.

[2] O.K. Baskurt, M. Uyuklu and H.J. Meiselman, Simultaneous monitoring of electrical conductance and light transmittance during red blood cell aggregation, Biorheology 46(3) (2009), 239-249.

[3] J.-F. Brun, M. Guiraudou, C. Mardemootoo, A. Traoré, I. Raingeard, A. Chalançon, and A. Avignon, Validation de la mesure segmentaire de la composition corporelle en comparaison avec la DEXA : Intérêt de la mesure de la masse grasse tronculaire, Science \& Sports (2013), 28 158-162.

[4] J.-F. Brun, E. Varlet-Marie, and J Mercier, Whole body bioimpedance as a mirror of the influence of hemorheological factors on electric properties of blood: A step forward with Hanai's mixture conductivity theory, Series on Biomechanics 25(1-2) (2010), 100-104.

[5] M. Guiraudou, L. Maimoun, J.-M. Dumas, M. Julia, I. Raingeard and J.-F. Brun, Composition corporelle mesurée par impédancemétrie segmentaire (BIAS) et performance de sprint chez les rugbymen./Body composition measured by bioimpedance segmental (BIAS) analysis and sprint performance in rugby players, Science \& Sports 30(5) (2015), 298-302.

[6] D.W. Hill and F.D. Thompson, The effect of haematocrit on the resistivity of human blood at $37^{\circ} \mathrm{C}$ and $100 \mathrm{kHz}$, Medical \& Biological Engineering \& Computing, (1975), 182-185.

[7] M.Y. Jaffrin and H. Morel, Body fluid volumes measurements by impedance: A review of bioimpedance spectroscopy (BIS) and bioimpedance analysis (BIA) methods, Medical Engineering \& Physics 30 (2008), 1257-1269.

[8] S. Kriemler, J. Puder, L. Zahner, R. Roth, C. Braun-Fahrländer, and G. Bedogni, Cross-validation of bioelectrical impedance analysis for the assessment of body composition in a representative sample of 6-to 13-year-old children, European Journal of Clinical Nutrition 63(5) (2008), 619-626.

[9] B. K. Lee, T. Alexy, R.B. Wenby and H.J. Meiselman, Red blood cell aggregation quantitated via Myrenne aggregometer and yield shear stress, Biorheology 44(1) (2007), 29-35.

[10] J.S. Lim, J.S. Hwang, J.A. Lee, D.H. Kim, K.D. Park, J.S. Jeong and G.J. Cheon, Cross-calibration of multi-frequency bioelectrical impedance analysis with eight-point tactile electrodes and dual-energy X-ray absorptiometry for assessment of body composition in healthy children aged 6-18 years, Pediatrics International 51(2) (2009), 263-268.

[11] C.H. Ling, A.J. de Craen, P.E. Slagboom, D.A. Gunn, M.P. Stokkel, R.G. Westendorp and A.B. Maier, Accuracy of direct segmental multi-frequency bioimpedance analysis in the assessment of total body and segmental body composition in middle-aged adult population. Clinical Nutrition 30(5) (2011), 610-615.

[12] G.A. Pop, Z.Y. Chang, C.J. Slager, B.J. Kooij, E.D. van Deel, L. Moraru, J. Quak, G.C. Meijer and D.J. Duncker, Catheter-based impedance measurements in the right atrium for continuously monitoring hematocrit and estimating blood viscosity changes; an in vivo feasibility study in swine, Biosensors and Bioelectronics 19(12) (2004), 1685-1693.

[13] G.A. Pop, T.L. de Backer, M. de Jong, P.C. Struijk, L. Moraru, Z. Chang, H.G. Goovaerts, C.J. Slager and A.J. Bogers, On-line electrical impedance measurement for monitoring blood viscosity during on-pump heart surgery, European Surgical Reseach 36(5) (2004), 259-265.

[14] A. Pribush, H.J. Meiselman, D. Meyerstein and N. Meyerstein, Dielectric approach to the investigation of erythrocyte aggregation: I. Experimental basis of the method, Biorheology 36 (1999), 411-423.

[15] A. Pribush, H.J. Meiselman, D. Meyerstein and N. Meyerstein, Dielectric approach to the investigation of erythrocyte aggregation. Part II. Kinetics of erythrocyte aggregation-disaggregation in quiescent and flowing blood, Biorheology 37 (2000), 429-441.

[16] A. Scafoglieri, J. Tresignie, E. Cattrysse, B. Sesboüé and J.-P. Clarys, Classical errors in traditional human body composition Erreurs fréquentes dans l'analyse classique de la composition corporelle, Science \& Sports 29(3) (2014), 119-124. 
[17] H. Schmid-Schönbein, E. Volger and H.J. Klose, Microrheology and light transmission of blood III: The velocity of red cell aggregate formation, Pflugers Archiv European Journal of Physiology 254 (1975), 299-317.

[18] S.C. Tjin, T. Xie and Y.Z. Lam, Investigation into the effects of haematocrit and temperature on the resistivity of mammalian blood using a four-electrode probe, Medical \& Biological Engineering \& Computing 36(4) (1998), 467-470.

[19] A.C. Utter and P.G. Lambeth, Evaluation of multifrequency bioelectrical impedance analysis in assessing body composition of wrestlers, Medicine \& Science in Sports \& Exercise, 42(2) (2010), 361-367.

[20] E. Varlet-Marie, I. Aloulou, J. Mercier and J.-F. Brun, Prediction of hematocrit and red cell deformability with whole body biological impedance, Clinical Hemorheology and Microcirculation 44(4) (2010), 237-244.

[21] E. Varlet-Marie and J.-F. Brun, Towards an indirect approach of hemorheology by total body bioelectrical impedancemetry, EuroSummer School on Biorhelogy, Varna, Bulgaria, June 29th - July 2nd, 2003. Proceedings, Sofia, (2004) pp. $121-126$.

[22] E. Varlet-Marie, E. Grubka, M. Karafiat, C. Fédou, E. Raynaud de Mauverger and J.-F. Brun, Comparaison de plusieurs formules de calcul de la masse maigre par bio-impédancemétrie avec l'absorptiométrie biphotonique (Dexa), Science \& Sports 24(3-4) (2009), 202-206. 